\title{
EUROPEAN STANDARDS FOR ASSESSING THE HEALTH OF A PERSON WHO PROBABLY SUSTAINED MISTREATMENT DURING DETENTION OR CUSTODY
}

DOI: 10.36740/WLek202012236

\author{
Olha H. Shylo ${ }^{1}$, Nataliia V. Glynska², Oleksii I. Marochkin ${ }^{1}$ \\ 'YAROSLAV MUDRYI NATIONAL LAW UNIVERSITY, KHARKIV, UKRAINE \\ ${ }^{2}$ ACADEMICIAN STASHIS SCIENTIFIC RESEARCH INSTITUTE FOR THE STUDY OF CRIME PROBLEMS NATIONAL ACADEMY OF LAW SCIENCES OF UKRAINE, \\ KHARKIV, UKRAINE
}

\begin{abstract}
The aim: The purpose of this paper is to identify and characterize the standards for assessing the health status of a person who is likely to have been mistreated during detention or custody.

Materials and methods: The provisions of international regulations, as well as the case law of the European Court of Human Rights (hereinafter - ECHR, Court) were studied in the preparation of the paper. A set of general scientific and special methods of cognition was used, in particular, the comparative-legal method, the system-structural method, the generalization method, the method of analysis and synthesis, and others.

Conclusions: Medical examinations and forensic examinations of persons detained or incarcerated and alleging torture or mistreatment are appropriate provided that they comply with European standards set out in the case law of the ECHR and the recommendations of international organizations, which whereas will ensure the effectiveness of formal investigations of such facts.
\end{abstract}

KEY WORDS: detainee's state of health, assessment of the detainee's state of health, medical examination, forensic examination, torture, mistreatment of a detainee

\section{INTRODUCTION}

Article 3 of the Convention for the Protection of Human Rights and Fundamental Freedoms ("the Convention") provides that no one shall be subjected to torture or to inhuman or degrading treatment or punishment. These Convention provisions are of particular importance in the field of criminal justice, where fundamental human rights, if there are appropriate grounds, are subject to significant restrictions. Thus, the right of a person alleging mistreatment to a proper medical examination, together with the right of access to a lawyer and the right to notify a third party about detention, are fundamental precautionary measures against mistreatment of detainees, and non-compliance indicates a violation of Art. 3 of the Convention. In order to ensure it, the following issues are relevant: conducting a full expert assessment of allegations of misconduct within the framework of a formal investigation by the competent authorities; proper doctor's qualification who conducts the medical examination of a person and examination to identify the torture signs; quality of the questions asked to the expert; promptness of the medical examination of a person claiming torture; elimination of contradictions in medical documentation, etc. Separate aspect of the problem of compliance with the requirements of Art. 3 of the Convention constitute such national models of investigation, as stated by the ECHR in many cases, in which the failure of authorities to promptly and thoroughly investigate allegations of mistreatment filed by persons suspected of committing crimes becomes systemic within the meaning of Art. 46 of the Convention [1].

\section{THE AIM}

The aim of this paper is to identify and characterize the standards for assessing the health status of a person who is likely to have been mistreated during detention or incarceration.

\section{MATERIALS AND METHODS}

In preparing the paper, the provisions of international regulations governing the medical examination and forensic examination of persons detained or incarcerated and alleging torture or mistreatment, the case law of the ECHR on these issues (for this purpose, ECHR's 21 relevant decisions were analyzed). It was used a set of general scientific and special methods of cognition, in particular, the comparative legal method, system-structural method, the method of generalization, the method of analysis and synthesis, and others to achieve the goal of the research.

\section{REVIEW AND DISCUSSION}

Article 3 of the Convention stipulates that no one shall be subjected to torture or to inhuman or degrading treatment or punishment. 
According to the established practice of the ECHR, when a person raises a well-founded complaint of a violation of Article 3 of the Convention, treatment by State agents, it is the duty of the authorities to conduct an "effective formal investigation" capable of establishing the facts and complaints will be true, until the culprits are identified and punished.

The minimum standards for the effectiveness of investigation, as established by the Court's case-law, require that it be independent, impartial and open to the public, and that the competent authorities act with exemplary diligence and efficiency [2].

During the investigation of torture or mistreatment of persons detained or incarcerated, the medical examination and forensic examination of the person alleging such treatment shall be of particular importance. Thus, in the cases of "Danilov v. Ukraine" and "Rudyak v. Ukraine" the ECHR noted that a medical examination, together with the right of access to a lawyer and the right to notify a third party of detention, are fundamental precautionary measures against mistreatment of detainees and should be applied from the outset of imprisonment. Such measures will not only guarantee the applicant's rights but will also enable the respondent Government to relieve themselves of the burden of providing a plausible explanation for these injuries $[1 ; 3]$.

A study of international human rights law and the administration of justice allow us to identify standards for assessing the health of a person who is likely to have been mistreated during detention or incarceration. In particular, such standards include: 1) conducting a full peer review of allegations of torture or mistreatment as part of an effective formal investigation; 2) compliance with the proper medical examination procedure of a person who has reported torture or mistreatment; 3 ) proper doctor's qualification who conducts the medical examination of a person who declared torture or improper treatment and the right to freely choose a doctor; 4) compliance with the requirements for the form and completeness of the medical opinion; 5) promptness of medical examination of a person who claims torture or misconduct; 6) providing evidence by a doctor regarding his/her conclusion. We will try to analyze the relevant decisions of the ECHR and the recommendations of international organizations and on this basis to draw some conclusions.

The peculiarity of the first standard (conducting a full expert assessment of allegations of torture or mistreatment in the framework of an effective formal investigation) is that on the one hand any allegation of torture or mistreatment by the competent authorities must be formally investigated and on the other - it is within the framework of such an investigation that a full expert assessment of the applicant's allegations must be carried out, as the ECHR has repeatedly emphasized in its decisions.

Thus, in the case of "Grigoryan and Sergeyeva v. Ukraine" ECHR, finding a violation of Art. 3 of the Convention, noted that the prosecutor's office had considered the applicant's complaint of mistreatment in the context of repeated investigations, and that no criminal proceedings had been instituted, which did not comply with the principles of effectiveness. Such a procedure significantly narrows the investigation, as it allows only a limited number of investigative actions. In particular, the Court pointed out that without initiating a criminal case, the authorities could not conduct a full expert assessment in order to eliminate inconsistencies in medical evidence [4].

Similar shortcomings of the investigation were found by the ECHR in the case "Strogan v. Ukraine", in which the Court found that the investigation had been limited to a medical examination of the applicant and the interrogation of police officers and other persons involved, and that no steps had been taken to resolve the discrepancies between the police and the applicant's testimony.

In other cases, there were the violations of these aspects of Art. 3 of the Convention, the ECHR stated that: the investigating authorities had not eliminated the inconsistency in the medical evidence from the case file [6], in particular, the inconsistency of the various expert opinions on the origin of the applicant's injuries had not been remedied [7]; according to the applicant's complaints of mistreatment, which was partially confirmed by the forensic examination report, no criminal proceedings had been instituted for more than two years [8]; this case investigation, which lasted more than seven years, did not go further than the trial by the Court of first instance, and the completeness and reliability of forensic examinations were questioned by investigators who repeatedly questioned experts and appointed additional examinations, etc. [9]. In the case of "Dolganin v. Ukraine" the ECHR noted a selective approach to the examination of the evidence, given that during the inspections the prosecutor's office had never mentioned that the results of the applicant's medical examination at the hospital indicated that he might have suffered an abdominal injury. The testimonies of the police officers, who allegedly took part in the alleged mistreatment, were accepted by the prosecutor's office, and the applicant's arguments were not verified.

Special attention should be paid to the importance of comprehensively recording (photographing) bodily injuries inflicted on the victim, as well as recording and storing evidence in the room where torture was reportedly used, as noted in paragraph 106 of the Istanbul Protocol (The Manual on Effective Investigation and Documentation of Torture and Other Cruel, Inhuman or Degrading Treatment or Punishment (hereinafter - Istanbul Protocol).

Otherwise, improper preservation of evidence of torture may lead to the ECHR recognizing a violation of the Convention. Thus, in the case of "Sizarev v. Ukraine" the Court found the investigation ineffective due to the fact that detention center administration did not take any measures to preserve the evidence, as immediately after the incident the traces of blood were washed away without prior inspection of the scene and drawing up a report [11].

The second standard concerns the proper medical examination of a person who has reported torture or mistreatment. The general requirements for this standard are 
contained in paragraph 124 of the Istanbul Protocol. Thus, in accordance with these provisions, the examination is carried out in the most suitable place in the opinion of the doctor and the victim, behind closed doors (outsiders remain outside the room); access to a lawyer must be provided.

The third standard (appropriate qualification of the doctor conducting the medical examination of a person who has reported torture or mistreatment and the right to freely choose a doctor) follows from the documents of the European Committee for the Prevention of Torture and Inhuman or Degrading Treatment or Punishment. According to these provisions, among the main guarantees of prevention of mistreatment of persons detained on suspicion of committing a crime is the right of a detainee to be examined by a doctor, which also includes the right to be examined by a doctor of his/her choice and receive adequate medical care [12].

In addition, to ensure proper medical examination of a person alleging torture or mistreatment, both the appropriate qualifications of the examiner, his/her specialization (ability to detect and record torture-related injuries) and initial examination are important. the applicant to detect signs of torture or mistreatment. Compliance with these requirements will facilitate the proper recording of injuries, which is essential given the inadmissibility of inspection delays.

In its practice, the ECHR draws attention to the above issues, emphasizing the importance of compliance with these standards. In particular, in the case of "Gerashchenko v. Ukraine" the Court noted that the Government had referred, in particular, to a medical certificate issued by a neurosurgeon stating that the applicant had not suffered any injuries which fell within his area of competence. The Court saw no reason to question this finding but noted that the scope of the examination was rather limited, as the doctor was not invited to assess the applicant's general health or to establish the presence or absence of injuries other than those of neurological origin. The grounds for this particular medical examination the day after the applicant's actual, but apparently undocumented, detention remained unknown [13].

In another case "Serikov v. Ukraine" the ECHR noted that an hour after the applicant's release from the police, he had suffered a number of injuries. The ECHR rejected the Government's argument that the ambulance paramedic had not recorded any injuries to him immediately before his release. Thus, the Court pointed out that the limits of paramedic's examination were limited and that its purpose was primarily to provide the applicant with emergency medical care and not to record his injuries [14].

The ECHR drew similar conclusions in the case of "Lunev v. Ukraine" with the only difference that the initial medical examination, which later led to numerous findings that applicant had not suffered any injuries, was superficial, as it appeared to be intended to establish whether the applicant had any health problems and whether he could have been in custody instead of being found to have been injured.

The next standard concerns compliance with the requirements for the form and completeness of a medical opinion. The main requirements for medical examination and medical opinion Istanbul Protocol (paragraph 162) include, in particular, objectivity and impartiality; proper professional doctors' experience and their special knowledge in documenting torture; clarity and comprehensibility of formulations and medical terminology, as well as indication of only the facts and all examination significant circumstances

Special requirements should be made to the content of the expert's report. Thus, Annex 1 to the Istanbul Protocol formulates the main issues to be reflected in the relevant expert document, which include, in particular: a) the survey circumstances (in particular, personal data of the subject and his/her condition; date and place of the survey, etc.); b) background (detailed description of the history reported by the respondent; methods of torture and complaints of symptoms, etc.);c) physical and psychological examination (report on all identified symptoms); d) conclusion (opinion on the possible connection of symptoms with probable torture); e) authorship of the report.

Paragraph 105 of the same document highlights the six most important questions to ask when drawing up a medical report in order to gather physical and psychological evidence of torture. Thus, such questions include the Istanbul Protocol's question of relationship between the established data and the report of probable torture; factors of physical condition of the subject and stress that affect the clinical picture; the ratio of obtained data with the expected or typical reactions to corresponding stress; stages of recovery of the subject; possibility of erroneous allegations of torture, etc.

The ECHR also emphasizes the importance of asking the right questions to experts in its decisions. Thus, in the case of "Chmil v. Ukraine" the Court has noted a violation of Art. 3 of the Convention, the Court stated that various investigative actions had been carried out during the investigation, including four forensic examinations. However, all these actions seem to have been rather superficial. In particular, with regard to forensic examinations, the Court noted that the experts had never been asked whether the applicant could have been injured in the circumstances described by him or in the circumstances described by the police officers [16].

In addition, it is important to pay attention to the recommendations on the specificity of the wording in examination conclusions, which the doctor sets out in the relevant document. Thus, according to $\$ 187$ of the Istanbul Protocol, the following terms are commonly used: a) does not correspond: the injury could not have been caused by the trauma described by the patient; $b$ ) answers: the injury could have been caused by the described injury, but it is not specific and could have been caused by a large number of other causes; c) high degree of conformity: the damage could have been caused by the described injury and the number of other possible causes was small; d) typically appearance of the injury is usually observed in this type of injury, but other causes are possible; e) makes a diagnosis: this appearance of the injury indicates that it could not 
have been caused by anything other than that described.

Finally, attention should be paid to another important issue, which concerns the possibility of taking into account both the conclusions of forensic medical examinations of public institutions and the conclusions of forensic medical examinations conducted by a private institution, in which the ECHR commented in "Nechiporuk and Yonkalo v. Ukraine". Thus, in the present case the ECHR stated that, on the one hand, the applicant had set out a detailed and consistent version, supported by a forensic examination carried out by a private institution, according to which he had been subjected to electric shock during his stay in the police station. On the other hand, the authorities' version, supported by official forensic findings, was that these injuries "could have been caused by blunt objects", without any further details and no comment on the forensic report of private institution, although it was attached to the materials of the criminal case against the applicant.

In the present case, the Court was strucked by the fact that the trial court ignored, as is apparent from its judgment, alternative medical report contained in the case file and confirmed what the applicant had complained about.

Another standard concerns the promptness of medical examination of a person who alleges torture or mistreatment. As a general rule, it is important to conduct a medical examination of the alleged victim of torture in a timely manner. At the same time, such an examination must be carried out regardless of how much time has elapsed since the use of torture until the traces of it have disappeared.

The ECHR emphasizes in the case "Bocharov v. Ukraine" on the importance of the very first medical examination of a person who alleges torture or mistreatment, noting that the initial results, in addition to those obtained after a direct examination of the applicant, in contrast to a later examination based on documents, were confirmed by the applicant's allegations of mistreatment and suspicious circumstances of his detention and custody [18].

In another case, "Pomilyayko v. Ukraine", the ECHR stated that due to the delay before the first forensic examination it had been impossible to draw precise conclusions as to the extent and nature of the applicant's injuries [19]. The ECHR reached essentially similar conclusions in the case of "A.N. v. Ukraine" [20].

Some cases of non-compliance with the promptness of medical examination of a person who alleges torture or mistreatment have been noted by the ECHR, in particular in the cases of "Ilhan v. Turkey" (medical examination of the applicant was conducted 36 hours after the event) [21]; "Kucheruk v. Ukraine" (forensic medical examination of the applicant's injuries was carried out 37 days after the incident) [22]. In these cases, these facts, together with other circumstances, allowed the ECHR to state a violation of Art. 3 of the Convention, in connection with the failure of the public authorities to provide a comprehensive and thorough examination of the applicants' injuries immediately after the relevant complaints, caused irreparable damage to the ability to establish the relevant facts.
In the studied context, the case "Danilov v. Ukraine", in which the ECHR noted the delays in gathering evidence, in particular because the fact that the applicant had broken seven ribs was established only four months after his detention, although he had complained of rib pain during the first medical examination, which took place within twenty-four hours after detention [1].

Finally, the last standard concerns the provision of evidence by a physician regarding his or her opinion. The purpose of the doctor's written or oral testimony, in addition to providing an expert opinion on the degree of compliance of the medical examination results with the patient's allegation of mistreatment, is also to report these results and relevant conclusions to the competent authorities or court (paragraph 122 of the Istanbul Protocol).

The ECHR also emphasizes the importance of interrogating an expert who conducted a medical examination and forensic examination. Thus, in the case of "Bocharov v. Ukraine" the Court, assessing the appropriateness of questioning the medical staff to clarify the case circumstances as fully as possible, noted that, despite the accuracy of the applicant's diagnoses, which were to play a key role in investigation, the case file did not show that any of the medical workers who examined the applicant shortly after his dismissal were questioned [18].

Referring to scientific sources, it should be noted that the issue of compliance with standards for medical examinations of detainees during the investigation of allegations of violence and torture against them in various contexts has already been raised in the literature $[23 ; 24 ; 25 ; 26 ; 27 ; 28 ; 29 ; 30]$. At the same time, foreign researchers consider this problem in two aspects: 1 ) in the context of ensuring the quality of medical examination of detainees and 2) in the context of the very fact of conducting a medical examination of detainees. In the first plane, British researchers, for example, draw attention to the problem of doctors' lack of necessary knowledge and criteria for identifying the facts of violence against detainees [31]. Similar issues are raised by Basoglu, M. [32], who provide guidance on the assessment and documentation of torture and the provision of medical care to victims of torture. Mostad K., Moati E. conclude that one of the main reasons for poor medical examination is the phenomenon of so-called doctors' "passive participation" in torture, which, in particular, is manifested in the provision of knowingly false medical opinions and failure to report torture. [33]. A similar position is covered by Modvig J, Rytter T. [34]. However, as noted by Silove D., Rees S. one of the factors that can lead to medical complicity in torture is double loyalty, through which doctors put the perceived interests of their organization or state before their absolute duty to care for their patient [35].

Regarding another aspect of medical examination of detainees, Spanish researchers, in particular, draw attention to the frequent cases of lack of information of detainees about their right to medical examination and deliberate violation of national and international norms on mandatory examination of detainees [36]. 


\section{CONCLUSIONS}

An analysis of the issue of assessing the health status of a person who is likely to have been mistreated during detention or incarceration in accordance with European standards allows us to draw the following conclusions.

First, models for investigating allegations of mistreatment of detainees or in custody in some European countries, including Ukraine, have been assessed negatively by the ECHR. The reluctance of the authorities to ensure a prompt and thorough investigation of allegations of mistreatment by persons suspected of committing crimes constitutes a systemic problem for these States within the meaning of Art. 46 of the Convention.

Secondly, in accordance with the case law of the ECHR and the recommendations of international organizations, the standards to be met by assessing the state of person's health likely to have been ill-treated during detention or custody include: 1) a full peer review of allegations of torture; misconduct within the framework of an effective formal investigation; 2) compliance with the proper procedure of medical examination of a person who has reported torture or mistreatment; 3 ) the appropriate qualifications of the physician conducting the medical examination of a person who reported the torture or mistreatment, and the right to freely choose the doctor; 4) compliance with the requirements for the form and completeness of medical opinion; 5) promptness of the medical examination of a person who claims torture or misconduct; 6) providing evidence by a physician regarding his/her conclusion.

Third, for the first time in 2012, the standard for conducting a full expert assessment of allegations of torture or mistreatment within the framework of an effective formal investigation was reflected in the national legislation of Ukraine. Thus, in accordance with Part 6 of Art. 206 of the Criminal Procedure Code of Ukraine if during any court hearing a person claims violence against him during detention or detention in an authorized public authority, public institution (public authority, public institution, which by law has the right to detain persons ), the investigating judge is obliged to record such a statement or accept a written statement from the person and 1) ensure the immediate conduct of a forensic examination of the person; 2) instruct the relevant body of pre-trial investigation to conduct an investigation of the facts set forth in the person's application; 3) take the necessary measures to ensure the safety of the person in accordance with the law.

The interpretation of this normative provision allows concluding that it is imperative for the pre-trial investigation body to enter information into the Unified Register of Pre-trial Investigations upon application and to conduct a formal effective investigation.

Fourth, at the national level, the problem of compliance with the standards to be met by assessing the state of health of a person who is likely to have been mistreated during detention or custody is largely in law enforcement, as recent high-profile examples show that the existence of a law that meets European standards, the legal awareness of law enforcement officers is quite low, which, in fact, is the cause of a flagrant violation of the law and their excess of official authority.

\section{REFERENCES}

1. Case of Danilov v. Ukraine (Application no. 2585/06) Judgment of 13 March 2014 Available from: http://hudoc.echr.coe.int/ rus? $\mathrm{i}=001-141625$ [reviewed 2020.08.10].

2. Case of Belousov v. Ukraine (Application no. 4494/07) Judgment of 7 November 2013 Available from: http://hudoc.echr.coe.int/ rus?i=001-127813 [reviewed 2020.08.10].

3. Case of Rudyak v. Ukraine (Application no. 40514/06) Judgment of 4 September 2014 Available from: http://hudoc.echr.coe.int/ rus?i=001-146356 [reviewed 2020.08.10].

4. Case of Grigoryan and Sergeyeva v. Ukraine (Application no. 63409/11) Judgment of 28 March 2017 Available from: http://hudoc.echr.coe.int/ rus?:=001-172323 [reviewed 2020.08.10].

5. Case of Strogan v. Ukraine (Application no. 30198/11) Judgment of 6 October 2016 Available from: http://hudoc.echr.coe.int/ rus?:=001-166957 [reviewed 2020.08.10].

6. Case of Yevgeniy Petrenko v. Ukraine (Application no. 55749/08) Judgment of 29 January 2015 Available from: http://hudoc.echr.coe. int/rus?i=001-150650 [reviewed 2020.08.10].

7. Case of Gordiyenko v. Ukraine (Application no. 27620/09) Judgment of 16 0ctober 2014 Available from: http://hudoc.echr.coe.int/ rus?i=001-147039 [reviewed 2020.08.10].

8. Case of Pankiv v. Ukraine (Application no. 37882/08) Judgment of 28 February 2019 Available from: http://hudoc.echr.coe.int/ rus? $\mathrm{i}=001-191275$ [reviewed 2020.08.10].

9. Case of Teslenko v. Ukraine (Application no. 55528/08) Judgment of 20 December 2011 Available from: http://hudoc.echr.coe.int/ rus?i=001-108189 [reviewed 2020.08.11].

10. Case of Dolganin v. Ukraine (Application no. 18404/07) Judgment of 16 February 2017 Available from: http://hudoc.echr.coe.int/ rus?i=001-171477 [reviewed 2020.08.11].

11. Case of Sizarev v. Ukraine (Application no. 17116/04) Judgment of 17 January 2013 Available from: http://hudoc.echr.coe.int/ rus? i=001-115883 [reviewed 2020.08.11].

12. Standards of European Committee for the Prevention of Torture and Inhuman or Degrading Treatment or Punishment (CPT). Available from: https://www.coe.int/en/web/cpt [reviewed 2020.08.11].

13. Case of Gerashchenko v. Ukraine (Application no. 20602/05) Judgment of 7 November 2013 Available from: http://hudoc.echr.coe.int/ rus?i=001-127809 [reviewed 2020.08.11].

14. Case of Serikov v. Ukraine (Application no. 42164/09) Judgment of 23 July 2015 Available from: http://hudoc.echr.coe.int/rus?i=001-156247 [reviewed 2020.08.11].

15. Case of Lunev v. Ukraine (Application no. 4725/13) Judgment of 22 October 2015 Available from: http://hudoc.echr.coe.int/ rus?i=001-157967 [reviewed 2020.08.12].

16. Case of Chmil v. Ukraine (Application no. 20806/10) Judgment of 29 0ctober 2015 Available from: http://hudoc.echr.coe.int/ rus?i=001-158139 [reviewed 2020.08.12]. [reviewed 2020.08.12].

17. Case of Nechiporuk and Yonkalo v. Ukraine (Application no. 42310/04) Judgment of 21 April 2011 Available from: http://hudoc.echr.coe.int/ rus?i=001-104613 [reviewed 2020.08.12].

18. Case of Bocharov v. Ukraine (Application no. 21037/05) Judgment of 17 March 2011 Available from: http://hudoc.echr.coe.int/ rus?i=001-103998 [reviewed 2020.08.12]. 
19. Case of Pomilyayko v. Ukraine (Application no. 60426/11) Judgment of 11 February 2016 Available from: http://hudoc.echr.coe.int/ rus? $\mathrm{i}=001-160428$ [reviewed 2020.08.12].

20. Case of A.N. v. Ukraine (Application no. 13837/09) Judgment of 29 January 2015 Available from: http://hudoc.echr.coe.int/ rus? $\mathrm{i}=001-150651$ [reviewed 2020.08.12].

21. Case of Ilhan v. Turkey (Application no. 22277/93) Judgment of 27 June 2000 Available from: http://hudoc.echr.coe.int/rus?i=001-58734 [reviewed 2020.08.12].

22. Case of Kucheruk v. Ukraine (Application no. 2570/04) Judgment of 6 September 2007 Available from: http://hudoc.echr.coe.int/ rus?i=001-82200 [reviewed 2020.08.12].

23. Picozzi M, Nicoli F, Ferrario 0. Medical Involvement in Acts of Torture or Degrading Treatment of Human Beings: Forensic and Medical Reflections, Bioethics - Medical, Ethical and Legal Perspectives, Peter A. Clark, Intech0pen. 2016. doi: 10.5772/65100

24. Vincent $R$, Beaufrère $A$, Chariot $P$, J. Detainees arrested for the first time in French police stations. Journal of Forensic and Legal Medicine. 2015; 31: 1-6. doi: 10.1016/j.jflm.2014.12.017

25. Beaufrère $A$, Belmenouar 0 , Chariot $P$. Elderly arrestees in police custody cells: implementation of detention and medical decision on fitness to be detained. Forensic Sci Int. 2014; 241: 15-19. doi: 10.1016/j. forsciint.2014.04.031

26. Rekrut-Lapa T, Lapa A. Health needs of detainees in police custody in England and Wales. Literature review. Journal of Forensic and Legal Medicine. 2014; 27: 69-75. doi: 10.1016/j.jflm.2014.08.004

27. Moscrop, A. Health Care in Detention: A Practical Guide. 2015. Available from:https://www.researchgate.net/publication/312489517_Health_ Care_in_Detention_A_Practical_Guide [reviewed 2020.08.12].

28. Méndez J E. Report of the Special Rapporteur on torture and other cruel, inhuman or degrading treatment or punishment. 2015, UN Doc A/HRC/28/68. Available from: https://www.refworld.org/ pdfid/550826644.pdf [reviewed 2020.08.12].

29. Right to an independent medical examination upon request. June 2018. Available from: https://www.apt.ch/sites/default/files/publications/ doc-3_right-to-a-medical-examination_en_final.pdf [reviewed 2020.08.20].

30. Carver R., Handley L. Does Torture Prevention Work? Liverpool University Press, Liverpool. 2016
31. McColl H., Bhui K., and Jones E. The role of doctors in investigation, prevention and treatment of torture. Journal of the Royal Society of Medicine. 2012; 105(11): 464-471.

32. Basoglu M. Rehabilitation of traumatised refugees and survivors of torture. BMJ. 2006;333:1230.

33. Mostad K, Moati E. Silent healers: on medical complicity in torture. Torture. 2008;18:150-160.

34. Polatin P.B., Modvig J., Rytter T. Helping to stop doctors becoming complicit in torture. BMJ. 2010;340:973.

35. Silove D., Rees S. Should psychiatrists assess torture?BMJ. 2010;340:124.

36. Vivancos C., Rivera I. Medical examination of detainees in Catalonia, Spain, carried out in the presence of police officers. Torture. 2020; 30(1):49-53.

\section{ORCID and contributionship:}

Olha H. Shylo: 0000000329638844 A, D, E, F

Nataliia V. Glynska: $000000018552445 X^{B, D, F}$

Oleksii I. Marochkin: $0000000203975036^{\text {B, D, F }}$

\section{Conflict of interest:}

The Authors declare no conflict of interest.

\section{CORRESPONDING AUTHOR Oleksii I. Marochkin}

Academician Stashis Scientific Research Institute for the Study of Crime Problems National Academy of Law Sciences of Ukraine Pushkinskaya str., 49, 61000, Kharkiv, Ukraine tel: +380661442985 e-mail: a.marochkin84@gmail.com

Received: 27.08 .2020 Accepted: 26.11 .2020

A - Work concept and design, B - Data collection and analysis, C - Responsibility for statistical analysis, D-Writing the article, $\mathbf{E}$-Critical review, $\mathbf{F}$ - Final approval of the article 